\title{
Biosensors Applications in Agri-food Industry
}

\author{
Liliana Serna-Cock and Jeyson G. Perenguez-Verdugo \\ Facultad de Ingeniería, Universidad Nacional de Colombia Sede Palmira \\ Colombia
}

\section{Introduction}

The dynamic worldwide agri-food market has produced increased biological, chemical and physical threats to food products, and a bigger consumer demand on process control, quality and safety of these products. As a result, farmers and processors are using technological tools to allow for the quick, effective and efficient determination of hazards inherent to safety and quality of products.

Biosensors are an important option in the agricultural and food sectors to control production processes and ensure food quality and safety by reliable, fast and cost effective procedures. Biosensors are promising alternatives to conventional analytical tools since they offer advantages in size, cost, specificity, rapid response, precision and sensitivity.

The agricultural and food industry integrates the production, processing and commercialization of agricultural materials for specific markets and consumer demands. Each step in the agricultural and food production chain is susceptible to several threats since agricultural materials and food products are transported to different parts of the world, favoring the loss of quality and the transmission of diseases.

The biological, chemical and/or physical threats may be the result of environmental contamination or failures during food handling, processing, packing and distribution. Detect, correct and prevent these failures are the basis for the development of quality management systems to ensure food safety.

According to the World Health Organization (WHO), each year millions of people around the world are affected by foodborne diseases. Biological risks produced by bacteria, viruses and biotoxins, chemical substances (e.g., additives), food nutrients used to add product value, pesticides, veterinary drugs residues, and processing operations and technologies that may generate polycyclic aromatic hydrocarbons (PAHs) derived from proteins decomposition, or mutagenic agents (e.g., tryptophan) in cooked foods, constitute risks to consumers health.

On the other hand, consumer demands have contributed to dramatic changes in the production and commercialization of foods, leading producers to search for innovative products and technologies. Furthermore, recent food crises have caused concerns regarding the safety of food products, resulting in increased sanitary standards. Today, food safety and food quality are key elements that influence consumers purchasing behavior. However, consumer perception varies with ethnicity, purchasing power, education level and awareness. Consequently, there are consumer groups that make purchasing decisions based on product price, regardless of food handling practices and potential public health risks; 
while other consumer groups, aware of the importance of quality, safety and traceability, demand foods with high quality and safety standards, such as healthy, fresh, organic and additives-free products and are willing to pay the added value.

Food-related conflicts, higher demands for novel and safe foods, and better consumer eating habits, have imposed challenges on food producers to minimize potential health risks and build consumer-producer relationships that offer confidence and security to customers. This requires the development of effective traceability technologies throughout the food chain. Within this frame, biosensor technologies surge as effective and efficient alternatives to control production processes and ensure food quality and safety.

Although the initial development in biosensor technologies was done in the biomedical field, the ability to detect, analyze and quantify molecules of different biological origins and the diversity of measuring principles, resulted in the creation of personalized biosensor designs to cover a wide range of technical needs. The various operating principles have allowed the creation of biosensors to analyze external substances in food products such as pesticides, fertilizers and dioxins residues, water and soil residues (accidentally incorporated to the food chain), genetically modified organisms, pathogenic microorganisms and their toxins, and food components such as antinutrients, allergens, drugs, additives, and hydrocarbons.

Regarding food quality, biosensors have been useful for the evaluation of food composition, particularly in food products from plant and animal origin that are transformed during postharvest and processing. The sensory properties and chemical composition will depend on factors such as storage temperature conditions, exposure to sunlight, oxygen level and best handling practices. However, if these factors are not well managed, catalytic and enzymatic processes can lead to the generation of substances that cause undesirable changes in texture, color, taste, smell and aroma. Also, biosensors can be used in products enriched with components such as vitamins, minerals, and antioxidants. They quantify the different food components to evaluate rancidity, maturity, decline and shelf life and detect substances used as indicators of food freshness.

Another agro-industrial application for biosensor is in controlling the various steps involved in the farm to consumer chain, which is vital in the development of modern industrial and manufacturing processes. Biosensors allow the manipulation and real time monitoring of variables such as $\mathrm{pH}$, temperature, pressure, oxygen, flow and volatile substances, affecting productivity, profitability and safety of food processing operations. Biosensors can also quantify compounds found in low or high concentrations (e.g., sugars, amino acids, alcohols, and acids), as they may become the limiting factors in a production process.

The detection of genetically modified organisms (GMO) is another useful application for biosensors, since several countries have laws regulating the commercialization of GMO products and their derivatives. Biosensors can also be useful in the implementation of hazard analysis and critical control points (HACCP) plans by verifying process developments and correcting errors in due time.

Biosensor technologies and nanotechnologies are being used together in many food and agricultural applications such as the development of nano-scale tools for biosafety, nanoscale compounds for food packaging, and nano-sensors for pathogen detection in animals and plants, among others. These are helpful tools in the detection and control of potential food contaminants by the agricultural and food industries.

In the first section of this chapter, we describe current biosensor applications for food security in two main areas: detection of foodborne pathogens and detection of chemical 
contaminants. Pathogens detection is important in the prevention of microbiological hazards acquired during the production, processing, storage, transportation and distribution of food products. We will highlight the use of biosensors for the detection of microorganisms responsible of large economic losses in the food industry due to productivity loss, medical costs and food product recalls, including Salmonella, Listeria monocytogenes, Campylobacter, and Escherichia coli. We give a comprehensive view on the role of biosensors in pathogens detection and discuss constraints such as pre-treatment requirements and analysis time. The detection of chemical contaminants outlines biosensor applications in the determination of contaminant residues including pesticides, fertilizers, heavy metals, food additives and antibiotics. Antibiotics are of great concern for consumer health since they create resistance to microorganisms. The importance of the appropriate HACCP plan implementation is discussed together with its impact in the meat, milk and honey processing industries. Examples of enzyme biosensors are presented, especially those with greater sensitivity and faster response time.

The second section covers biosensors as low-cost, easy to use analytical tools for the fresh product industry, with emphasis on food quality, as defined by food nutritional value, safety, and acceptability. Food quality is evaluated through organoleptic parameters (freshness, appearance, taste and texture), where food composition allows the verification of the type of elements present in a given food. In this case, biosensors are used for the quantification of starch, glucose, lactose, lecithin, and ethanol as indicators of quality and consumer acceptability. We also describe the use of biosensors for the evaluation of freshness and shelf life. The detection of polyphenols in olive oils, short-chain fatty acids in milk and dairy foods, amines formation in fish; rancidity evaluation; quantification of glucose and fructose as indicators of fruit ripening and firmness, are among the various applications described in the second section.

The last section describes the use of biosensors in controlling processing operations, including HACCP plans. The importance in productivity, performance and efficiency in biotechnological processes is discussed and the online identification and quantification of various compounds (e.g., amino acids, sugars and alcohols) is highlighted. These determinations allow the monitoring of high or low concentrations of components that significantly affect the processing of foods. In the case of sugars, we will describe amperometric biosensors used to determine glucose using glucose oxidase in fruit juices, lactose using $B$-galactosidase and glucose oxidase, and lactulose using $B$-galactosidase and fructose dehydrogenase (an enzyme used as indicator of excessive thermal processing of milk). We will also describe the use of amperometric biosensors for the determination of alcohol using the enzyme dehydrogenase from Gluconobacter oxydans. Emphasis will be given to the monitoring of fermentation processes, including the description of interfering compounds (e.g., ascorbic acid and tyrosine), procedures to remove such compounds, and correction methods that reduce the duration of the analysis, including filtration, evaporation and acid or alkaline hydrolysis. Biosensors characteristic such as specificity, analysis time, automation, and sensitivity will be discussed. Finally, the challenges facing the food industry and the new trends in biosensors technology are presented.

\section{Biosensors in food security}

Food Security refers to the availability and continuous, timely and permanent access to foods that meet quality and safety standards by the entire world population (FAO, 1996). 
Food agro-industrialization is a strategy that allows guaranteeing the continuous availability of foods. However, physical, biological, and chemical hazards from preharvest to storage and final product marketing, may affect food quality and safety.

Physical pollutants affect the quality of food components, mainly influencing product appearance and causing rejection by consumers. To prevent physical damage, it is necessary to maintain control over every stage of the process, and manage logistics, including the compliance with personnel safety standards and the assurance of good infrastructure conditions in the food industry.

Biological hazards are primarily caused by microorganisms and their toxins, which may or may not affect the organoleptic properties of foods but nevertheless affect consumer health. Food poisoning and infections have a strong economic and social impact, causing loss of productivity due to morbidity and mortality (Vásquez de Plata, 2003).

Microorganisms involved in biological hazards that require specific processing interventions include bacteria belonging to the genus Salmonella, Shigella, Escherichia coli, Listeria monocytogenes and Clostridium botulinum. Microbiological analyses during processing and on final products have been traditionally used to assure the control of these pathogens. These methods are based on the detection of potential pathogenic microorganisms through their isolation in differential and selective growth media, requiring long response times (ranging from 48 hours to 5 days), and also involving high identification costs (Meng \& Doyle, 2002).

Another traditional method for the detection of pathogens in food and human and animal biological tissues is through enzyme-linked immunosorbent assays (ELISA) (Arbault et al., 2000; Nowak et al., 2007; Deng et al., 2008; Cabrera et al., 2009). The ELISA test is based on qualitative or quantitative color changes, using an enzyme as a reaction biomarker between an antigen and an antibody. If the substrate of the enzyme is cromogenic, a strong color change will indicate a greater concentration of the analyte (Sismani et al., 2008). However, the reuse of antibody receptors linked to enzymes increases the cost of detection, as well as the limited sensitivity of antibodies increases the possibility of unreliable results in a rapid test (Turner et al., 2009).

Biosensors offer rapid and effective detection options to control biological hazards. Biosensor technologies are advantageous due to the potential for miniaturized, rapid, specific, and sensitive detection of biological hazards (Pathirana et al., 2000; Ropkins \& Beck, 2000).

\subsection{Biosensors used for the detection of bacteria \\ 2.1.1 Salmonella}

Salmonella are Gram-negative bacteria naturally found in the gastrointestinal tract of warmblooded animals and humans (Nowak et al., 2007; Lu et al., 2009). When out of their natural habitat, these bacteria are able to survive in water and food products. The consumption of contaminated food products causes diseases such as enteric fever and salmonellosis.

The majority of food processing plants are not equipped with water purification systems, and Salmonella becomes the principal biological contamination hazard (White et al., 2002).

For the rapid detection of Salmonella, piezoelectric antigen-antibody biosensors are used. These sensors may apply the Langmuir-Blodgett (LB) monolayer method, which is based on the immobilization of amphiphilic antibodies. The antibodies are captured and distributed uniformly in a liquid having affinity to the antibody. Antibodies can be monoclonal or polyclonal; however, the use of monoclonal antibodies is ideal because it offers greater specificity. As shown in Figure 1, when submerging a support probe with a polar and a nonpolar surface, little interaction with the antibody occurs. However, binding between the 
antibody and the polar surface (antibody film) will occur when the support emerges from the liquid. The support will have transduction resonance properties, i.e., when affinity with antigen takes place, the resonance frequency will be affected due to increased mass in the crystal support (Guntupalli et al., 2007).

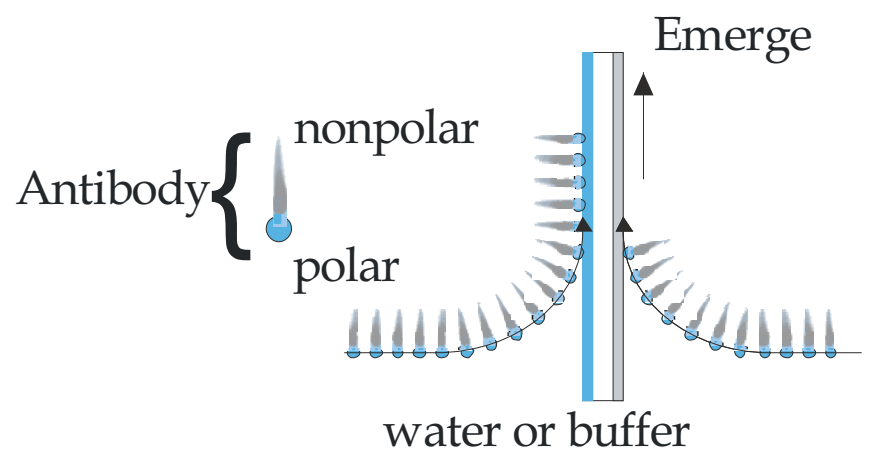

Fig. 1. Antibodies film formation in the support following the Langmuir-Blodgett technique when emerging from the solution.

The sensor platform used by Guntupalli et al. (2007) is made of magnetostrictive $\mathrm{Fe}_{40} \mathrm{Ni}_{38} \mathrm{Mo}_{4} \mathrm{~B}_{18}$ and immobilized polyclonal rabbit antibodies using the LB method to detect Salmonella typhimurium by measuring changes in surface pressure by the Wilhelmy method. The system reaches equilibrium in the surface in order to reduce vibrations generated by external factors, in such a way that frequency and amplitude changes are only caused by mass variations in the crystal. This method was studied using different biosensor sizes and it was concluded that better changes in resonance frequency were achieved with small sensors. In these sensors, the resonance frequency decreases with an increase in the number of pathogen microorganisms bound to the antibody. As a consequence, to detect Salmonella it is convenient to use bigger biosensors since smaller ones would not allow enough contact area with the antigen, and low pathogen concentrations would not be detected. Figure 2 shows the common detection method for pathogens or bacterial cells by using a resonance magnetoelastic biosensensor.

Many Salmonella detection studies focus on this type of biosensors. The advantage of using these biosensors with antibodies as the recognition element is their high specificity, sensitivity, chemical stability and rapid response; however, as mentioned earlier, the low specificity achieved by polyclonal antibodies may be a drawback in some sensors. These biosensors are used in water sanitation control, which is required in all food transformation processes. They are also used in milk production and in the control of milk products, including milking equipment, pollution system, pumps, farms or livestock stables, processing industry and finished products.

\subsubsection{Listeria monocytogenes}

Listeria monocytogenes, a Gram positive, flagellate microaerophilic coccobacillus, can cause listeriosis associated to the consumption of fresh and processed foods such as meats, 

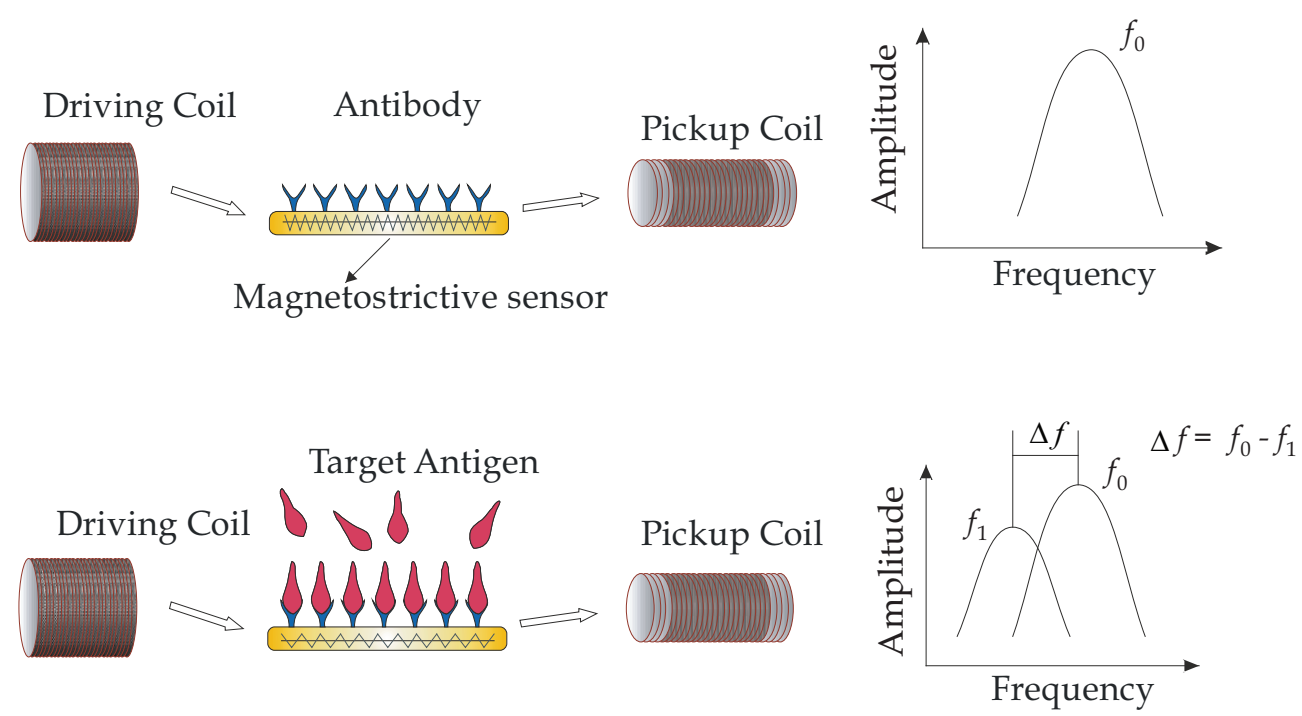

$\Delta f$ is the shift in frequency due to antigen binding

Fig. 2. Detection of pathogens or bacterial cells using a magnetoelastic resonant biosensor by the change in amplitude of the resonant wave, due to frequency variation when the analyte binds to the receptor (Guntupalli et al., 2007).

shellfish, unpasteurized milk and vegetables (Sánchez et al., 2009). The disease produces little morbidity but important mortality in humans and animals, with symptoms such as muscle pain, nausea, diarrhea and chills. Complications are serious since it affects the central nervous system, causing seizures, headaches and even comatose state. Similarly to the bacteria genus Salmonella, L. monocytogenes has had negative repercussions at productive, economic and social levels (FAO/WHO, 2004).

Unlike E. coli and Salmonella, Listeria monocytogenes can grow at refrigeration temperatures, being only inactivated by high temperature and pasteurization treatments (FAO/WHO, 2004). Due to its ability to adapt to a wide range of $\mathrm{pH}$ and temperatures, it is associated with silage or poorly fermented foods. Organic acids, such as lactic acid produced during fermentation, inhibits the growth of Listeria monocytogenes at $\mathrm{pH}<5.2$ being more effective than inorganic acids such as hydrochloric acid $(\mathrm{HCl})$, where the bacteria can growth at $\mathrm{pH}$ 4.8 (Pellicer et al., 2009).

A rapid detection of this pathogen is essential. Biosensors offer advantages over traditional methods that need longer test time and specific growth media before the pathogen is detected (Geng et al., 2004). The use of optical biosensors allows the reaction between receptor and analyte, providing confidence, specificity and less time for detection. The excitation of atoms related to the receptor-analyte reaction, results in mass, energy, and physical changes that are captured by the biosensor. In this way, real time data is used to identify bacteria, viruses or toxins. Moreover, these biosensors allow the identification of pathogens at low concentrations (Geng et al., 2004).

A fiber-optic biosensor can be used for the detection of Listeria monocytogenes (Geng et al., 2004). It is based on the measurement of fluorescent light generated by a wave when there is a change in resonance. The biosensor uses monoclonal fluorescent antibodies that generate 
excitation of atoms and wave production when bound to the pathogen. The biosensor is made of a polystyrene support that immobilizes the antibodies. The antibodies are obtained by inducing the immune response of rabbits after inoculating with Listeria monocytogenes for three months (Leonard et al., 2004). The quick response from this biosensor and the specificity against L. monocytogenes were verified in the presence of bacterial pollutants common in foods such as E. coli, Enterococcus faecalis, and S. enteric. Its response in cold $\left(4{ }^{\circ} \mathrm{C}\right)$ and salty conditions showed lower reaction rates due to "stress" of the monoclonal antibodies at low temperatures. The biosensor also showed a reduction in sensitivity at low L. monocytogenes concentrations when the medium contained other microbiota able to affect the antigen-antibody reaction (Geng et al., 2004). The fiber-optic biosensor detects concentrations from $10^{7}$ to $10^{8} \mathrm{CFU} / \mathrm{ml}$ (Geng et al., 2004). In situations where the product is suspected to contain L. monocytogenes counts below $10^{7} \mathrm{CFU} / \mathrm{ml}$, an enrichment step prior to the biosensor detection is required.

Although optical biosensors have been widely implemented for the detection of $L$. monocytogenes, biosensors using surface plasmon resonance (SPR) had shown better response. Although SPR sensors are more expensive than fiber optic sensors, they are the best alternative for a rapid - 5 to 15 minutes - detection (Van der Merwe, 2011). In addition, low concentrations of bacteria $\left(10^{5} \mathrm{~L}\right.$. monocytogenes $\left.\mathrm{CFU} / \mathrm{ml}\right)$ can be identified (Leonard et al., 2004), thus sample enrichment prior to analysis is not required.

SPR biosensors have disadvantages that are important to consider too, such as wear of the miniaturized and thin plate or support where the light wave contacts the sensor. The use of these biosensors for high-performance detection tests is not recommended. The efficiency, speed and sensitivity of the biosensor increases when the analytes are large molecules such as cells (Van der Merwe, 2011), since mass change on the surface is the basis for detection (Van der Merwe, 2011).

Fiber optic and SPR biosensors help preventing the spread of foodborne illnesses and ensure food safety in processed and minimally processed foods. In addition, their nano-scale dimensions offer advantages for handling, transporting, storing, processing, and distributing foods.

\subsubsection{Campylobacter}

The genus Campylobacter, are Gram negative bacteria, characterized for being microaerophiles (oxygen concentrations between 3-5\%), comma-shaped or "S" flagellates, with motility (Ryan \& Ray, 2010).

Infections caused by these bacteria are the main cause of gastroenteritis, being very frequent in children. Campylobacteriosis causes symptoms such as fever, abdominal pain, diarrhea, vomiting, and nausea. The disease has side effects including reactive arthritis and muscle pain due to alterations in the immune system (WHO, 2000). Campylobacter can be found in poultry and other birds, cattle, and even seafood (WHO, 2000). Poor cooking practices in processed meats and dairy products further favor the spread of this thermophilic bacterium. An efficient and opportune detection prevents the spread infections among animals and humans. Traditional microbiological methods for the identification of Campylobacter require 3 to 4 days (Wei et al., 2007). The difficult phenotypic characterization further complicates the proper identification of the bacteria (On, 2001). In this case, biosensors are also reliable for a rapid detection of the microorganism.

A SPR optical biosensor has great sensitivity for Campylobacter, being capable of rapidly detecting concentrations of Listeria monocytogenes having the specific antibody for 
Campylobacter populations of at least $10^{3} \mathrm{CFU} / \mathrm{ml}$ (Wei et al., 2007). To obtain these results, four antibodies from different manufacturers were used and reactivity, specificity and sensitivity tests were done, showing a maximum detection dilution of $1 / 200$ for the chosen antibody. Reactivity tests were verified with an ELISA test, using inhibitors and denaturing agents to check whether the bacteria could be detected by antibodies even after inactivation. High temperature pretreatments did not result in changes in the detection capabilities of the biosensor. The specificity of the biosensor was also tested by the binding between the antibody and Campylobacter in the presence of other bacteria. Other bacteria exhibited temporary union with the antibody due to a weak association promoted by precipitation with glycine buffer. The sensitivity of the SPR biosensor was tested in pure bacterial populations ranging from $10^{1}$ to $10^{8} \mathrm{CFU} / \mathrm{ml}$, with adequate detection starting at populations of $10^{3} \mathrm{CFU} / \mathrm{ml}$ (Wei et al., 2007).

Campylobacteriosis illness is mainly spread by eating contaminated food, being a major problem in poultry production. Optical SPR biosensors are not the only detection methods, but other types of recognition elements such as DNA, RNA, enzymes, and tissues could be implemented; since interactions with other types of cells and/or macromolecules may probably occur.

\subsubsection{Escherichia coli}

Escherichia coli is a Gram negative bacilli normally inhabiting the intestine of humans and warm blooded animals (Darnton et al., 2007). An E. coli strain, known as 0157:H7, may cause inflammation in the small intestine, causing severe diarrhea (including bleeding) and kidney damage (Lin et al., 2010). These bacteria are also responsible for the hemolytic uremic syndrome (Waswa et al., 2007), which is an infectious and contagious disease characterized by kidney failure, microangiopathic hemolytic anemia, thrombocytopenia, coagulation defects and other neurologic disorders.

The infection caused by E. coli results from ingesting food, mainly fresh fruits and vegetables, and/or contaminated water. Infections may also be caused by eating poorly cooked animal foods or foods that were washed with contaminated water (WHO, 2005).

Animal derived foods such as raw milk can have a high E. coli count, either due to inadequate feeding of animals or diseases such as bovine mastitis, resulting from poor cleaning of processing equipment and/or inadequate sanitation practices.

E. coli grows at temperature ranging from 7 to $50{ }^{\circ} \mathrm{C}$, and has the ability to grow in acid foods with $\mathrm{pH}$ down to 4.4 and with low water activity. Therefore, a minimum of $70{ }^{\circ} \mathrm{C}$ in the food is required to inactivate the bacteria (WHO, 2005).

When considering the effects that infections may produce in human and animals through food and water, traditional detection methods for $E$. coli that require 24 to 48 hours are considered time consuming and costly. Therefore, fast, simple, efficient and cost-effective methods are needed, and the development of biosensors may play a key role in detecting small E. coli concentrations (Gfeller et al., 2005).

There are different methods for a rapid detection using biosensors with detection limits down to $10^{3} \mathrm{E}$. coli CFU/ml in less than 10 hours and confirmation using PCR (Tims \& Lim, 2003). Other techniques use biosensors for detecting bacteria by flow cytometry followed by inmunomagnetic separation. This technique can detect down to 4 cells/g of $E$. coli in beef, in a 7 hours time frame (Seo et al., 1998).

E. coli detection in shorter time has been done using amperometric biosensors, through the detection of hydroxyl radicals produced by E. coli oxygen reduction during aerobic 
metabolism (Tang et al., 2006). This technique uses the covalent immobilization of enzymes lactase and peroxidase on indium and tin oxides, and the oxidation of salicylic acid to polyphenolic compounds by hydroxyl radicals. Enzymes can act on polyphenolic compounds, where the enzyme lactase in presence of oxygen produces quinones and peroxide residues that serve as electron donors and the enzyme peroxidase catalyzes the reaction on other polyphenolic compounds. The latter reaction also generates quinones, producing a reversible reaction measured by the amperometric biosensor. The amount of polyphenolic compounds generated through the microbial metabolic cycle depends on the concentration of $E$. coli cells.

\subsection{Biosensors used for the detection of contaminant residues and pesticides}

Pesticides (herbicides, fungicides, and insecticides) are used worldwide due to their wide range of activity. The presence of pesticide residues and metabolites in food, water and soil currently represents one of the major issues in environmental chemistry research (Mostafa, 2010). Due to their increasing use in agriculture, pesticides are among the most important environmental pollutants. However, the existing analytical methods for the determination of organophosphate pesticides and N-methyl carbamates are complex or not existent for some compounds. High Performance Liquid Chromatography (HPLC) is an appropriate technique for the determination of these compounds since it preserves pesticide stability. However, to set the adequate sensitivity for the method, several pretreatment steps are required, adding time and cost (Hiemstra \& De Kok, 1994). Due to the restrictions in conventional methodologies, the development of biosensors for direct and indirect pesticide detection is of particular interest. Serna et al. (2009) discussed the use of most common enzymatic biosensors for the detection of pesticides, fertilizers, and heavy metals. Table 1 shows the biosensors that have been reported in the literature since 2004 for direct detection of pesticides.

Enzymes like cholinesterase (AChE, BChE), organophosphorus-hydrolase (OPH), and urease are used in the design of electrochemical biosensors for pesticides detection. Analytical devices, based on $\mathrm{OPH}$ and cholinesterase inhibition, have been widely used for the detection of carbamates (Zhang et al., 2005) and organophosphate compounds (OP) (Pavlov et al., 2005). OPH, an organophosphotriester hydrolyzing enzyme, has broad substrate specificity and is able to hydrolyze a number of OP pesticides such as paraoxon, parathion, coumaphos, diazinon, and dursban. Organophosphorus acid anhydrolase catalyzed hydrolysis of OP compounds generates two protons as a result of the cleavage of the P-O, P$\mathrm{F}$, substitution or P-CN bonds and an alcohol, which in many cases is chromophoric and/or Electroactive (Mostafa, 2010). The resulting reaction ions are detected through potentiometric biosensors. Another way to detect the action of the enzyme OPH is by monitoring, through amperometric biosensors, oxidation and reduction reactions occurred by the hydrolysis of the substrate.

$\mathrm{OPH}$ was used in a biosensor for the detection of paraoxon and parathion. The transducer structure of the sensor chip consists of a $\mathrm{pH}$ sensitive electrolyte-insulator- semiconductor (EIS) structure that reacts to $\mathrm{pH}$ changes caused by the OPH catalyzed hydrolysis of the organophosphate compounds (Schöning et al., 2003). Conductimetric AChE biosensors have been used to evaluate the toxicity of methyl parathion and its photodegradation products in water (Dzyadevych et al., 2002). Similarly, biosensors using immobilized enzymes for the detection of OP parathion hydrolase immobilized in a coal electrode have been developed. The organophosphorus parathion hydrolase hydrolyzes parathion on p-nitrophenol and it is 
detected by its anodic oxidation (Schöning et al., 2003). Immobilized cells of Flavobacterium $s p$ have been used for the detection of methyl parathion. Whole cells of Flavobacterium sp. were immobilized by trapping in glass fiber filter and were used as biocomponents along with optic fiber system. Flavobacterium sp. has the enzyme organophosphorus hydrolase, which hydrolyzes the methyl parathion into detectable product $p$-nitrophenol (Kumar et al., 2006).

Biosensors based on BChE are very sensitive in the detection of OP pesticide mixtures such as clorfenvinfos and diazinon. Immunochemical techniques, including the piezoelectric immunosensors, are gaining acceptance as alternative or complementary methods for the analysis of pesticides. Immunosensors have great potential for monitoring herbicides in drinking water (Yokoyama et al., 1995; Székács et al., 2003), dioxins concentration in real environmental samples (Park et al., 2006), and the detection of polychlorinated terphenyls (biphenyls) (Pribyl et al., 2006) and atrazine (Pribyl et al., 2003) among others.

Piezoelectric immunosensors "can be considered as alternatives comparable to other wellestablished immunochemical methods such as ELISA. In contrast to the ELISA techniques that require labeling of reactants and about two hours per assay, this technique can be automated, does not use markers and analysis results are available in a few minutes" (Ocampo et al., 2007).

An inmunosensor is a biosensor using antigen-antibody reactions as the basis for detection. Usually, the analyte contains the antigen or hapten and the antibody is attached to the receptor. It is important to note that pesticides are generally small molecules that do not produce immune response, and then it is necessary to unite these compounds to inmunogenic molecules like proteins (haptens), keeping intact the chemical composition of the compound to be analyzed. The design of the specific hapten is decisive in the development of immunoassays, since it is responsible for determining the recognition characteristics of the antibody (Haasnoot et al., 2000).

The piezoelectric inmunosensor uses a crystal quartz micro scale, in which the antigen, a conjugate or an antibody, is immobilized to the glass surface. The antigen-antibody reaction is detected by the oscillating piezoelectric crystal quartz that resonates at a fundamental frequency and has a linear behavior with respect to its surface mass density. The operation of piezoelectric resonators in liquid phases includes changes in the mass induced frequency and effects induced by the change in viscosity or density of the surrounding liquid layers (Kim et al., 2007; Fohlerová et al., 2007).

There are also other potentially toxic substances for humans, such as contaminated residues present in water and soil, with a major impact on the environment accidentally reaching the food chain (Serna et al., 2009). Some of these residues are by-products from diverse industrial processes (dioxins) used as dielectric or hydraulic fluid agents (polychlorinated biphenyls or PCBs) or generated from fossil fuels or wood burning (polycyclic aromatic hydrocarbons or PAHs), benzene, toluene and xylene (named BETX) and derived phenolics. Immuno-, enzymatic, and bio- sensors with complete cells are used for the detection of these organic compounds (Patel, 2002).

\subsection{Biosensors used for the detection of heavy metals}

Heavy metals are toxic substances that accumulate in the organism and cause metabolic alterations since there is no way of metabolizing or excreting them. We may accumulate heavy metals when eating foods of animal origin, since animals have greater contact with poorly treated water, can graze close to industries, and even eat foods treated with water contaminated with heavy metals. 
Diseases caused by the ingestion if heavy metals include cardiovascular and respiratory problems, infertility, irritations, inhibition of some hormonal activities, malfunction of the principal organs, and death.

Devices have been designed to determine the concentration of heavy metals such as arsenic, cadmium, mercury, and lead, in water and soil samples. These devices incorporate genetically modified microorganisms and enzymes such as urease, cholinesterase, glucose oxidase, alkaline phosphatase, ascorbate oxidase and peroxidase (Tsai et al., 2003), incorporated to electrochemical and optical transduction systems.

Bi-enzymatic biosensors are used to detect enzymes inhibition in water. Enzymes like alkaline phosphatase and acetyl cholinesterase are inhibited by the presence of heavy metals, carbamates and organophosphates. Conductometric biosensors use immobilized Chlorella vulgaris microalgae as bioreceptors. Chouteau et al. (2005) immobilized algae inside bovine serum albumin membranes reticulated with glutaraldehyde vapors deposited on interdigitated conductometric electrodes. Local conductivity variations caused by algae alkaline phosphatase and acetylcholinesterase activities could be detected.

In addition, it is possible to detect the presence of cadmium through transduction systems based on fiber optics. The biosensor detects the inhibition of the enzyme urease, can sense down to $0.1 \mathrm{~g} / 1$ of cadmium in milk. The device can be constructed from whole cells of Bacillus badius with phenol red as an indicator co-immobilized onto circular plastic discs with sol-gel approach and fiber optic transducer system. Urea is added to the plastic disc to detect the inhibition of enzymatic reactions (Verma et al., 2010).

Other methodologies used in the detection of heavy metals are shown in Table 1.

\begin{tabular}{|c|c|c|c|c|}
\hline Analyte & $\begin{array}{l}\text { Type of } \\
\text { interaction }\end{array}$ & $\begin{array}{l}\text { Recognition } \\
\text { biocatalyzer }\end{array}$ & $\begin{array}{l}\text { Transduction } \\
\text { system }\end{array}$ & References \\
\hline \multicolumn{5}{|l|}{ Pesticides } \\
\hline Methyl Parathion & Biocatalytic & $\begin{array}{l}\text { Sphingomonassp. } \\
\text { Flavobacteriumsp } \\
\text { Methyl parathion } \\
\text { hydrolase. } \\
\text { Acetyl } \\
\text { Cholinesterase }\end{array}$ & $\begin{array}{l}\text { Fiber optic } \\
\text { Amperometric. } \\
\text { (square wave } \\
\text { voltammetric). } \\
\text { Electrochemical }\end{array}$ & $\begin{array}{l}\text { Kumar \& } \\
\text { D'Souza, } 2010 \\
\text { Kumar et al., } 2006 \\
\text { Chen et al., } 2010 \\
\\
\text { Gong et al., } 2009\end{array}$ \\
\hline Organophosphorus & Biocatalytic & $\begin{array}{l}\text { Organophosphorus } \\
\text { hydrolase }\end{array}$ & Amperometric & Deo et al., 2005 \\
\hline Triazophos & Biocatalytic & $\begin{array}{l}\text { Acetyl } \\
\text { Cholinesterase }\end{array}$ & Amperometric & $\begin{array}{l}\text { Du et al., 2007; } \\
\text { Du et al, } 2010\end{array}$ \\
\hline $\begin{array}{l}\text { Monocrothopos, } \\
\text { Malathion, Metasystox } \\
\text { and Lannate }\end{array}$ & Biocatalytic & $\begin{array}{l}\text { Acetyl } \\
\text { Cholinesterase }\end{array}$ & Electrochemical & Dutta et al, 2008 \\
\hline $\begin{array}{l}\text { Chlorpyrifos- } \\
\text { Oxon, } \\
\text { Chlorfenvinphos, } \\
\text { Pirimiphos-methyl, } \\
\text { Malathion,Carbofuran, } \\
\text { Methomyl and } \\
\text { Carbendazim }\end{array}$ & Biocatalytic & $\begin{array}{l}\text { Acethyl } \\
\text { Cholinesterase }\end{array}$ & Amperometric & $\begin{array}{l}\text { Hildebrandt } \\
\text { et al., } 2008\end{array}$ \\
\hline
\end{tabular}




\begin{tabular}{|c|c|c|c|c|}
\hline Analyte & \begin{tabular}{|l|} 
Type of \\
interaction
\end{tabular} & \begin{tabular}{|l|} 
Recognition \\
biocatalyzer
\end{tabular} & $\begin{array}{l}\text { Transduction } \\
\text { system }\end{array}$ & References \\
\hline Acetylcholine & Biocatalytic & $\begin{array}{l}\text { Choline oxidase } \\
\text { and Acethyl } \\
\text { Cholinesterase }\end{array}$ & Amperometric & $\begin{array}{l}\text { Shimomura } \\
\text { et al., } 2009\end{array}$ \\
\hline \multicolumn{5}{|l|}{ Fertilizers } \\
\hline Nitrate & Biocatalytic & Nitrate reductase & Potentiometric & $\begin{array}{l}\text { Sohail \& Adeloju, } \\
2008\end{array}$ \\
\hline Nitrite & Biocatalytic & Nitrite reductase & $\begin{array}{l}\text { Voltammetric } \\
\text { Amperometric }\end{array}$ & $\begin{array}{l}\text { Almeida et al., } 2007 \\
\text { Silveira et al., } 2010\end{array}$ \\
\hline Phosphate & Biocatalytic & $\begin{array}{l}\text { pyruvate oxidase } \\
\text { Maltose } \\
\text { phosphorylase. } \\
\text { pyruvate oxidase }\end{array}$ & $\begin{array}{l}\text { Amperometric } \\
\text { Conductometric } \\
\text { Voltammetric and } \\
\text { Amperometric }\end{array}$ & $\begin{array}{l}\text { Rahman et al, } 2006 \\
\text { Zhang et al., } 2008 \\
\text { Akar et al., } 2010\end{array}$ \\
\hline Urea & Biocatalytic & Urease & $\begin{array}{l}\text { Amperometric } \\
\text { Potentiometric }\end{array}$ & \begin{tabular}{|l|} 
Kuralay et al., 2006 \\
Trivedi et al., 2009 \\
\end{tabular} \\
\hline \multicolumn{5}{|l|}{ Heavy metals } \\
\hline $\mathrm{Hg}, \mathrm{Ag}, \mathrm{Pb}$ and $\mathrm{Cd}$ & Biocatalytic & $\begin{array}{l}\text { Invertase and } \\
\text { glucose oxidase }\end{array}$ & ultramicroelectrode & $\begin{array}{l}\text { Bagal-Kestwal } \\
\text { et al., } 2008\end{array}$ \\
\hline $\begin{array}{l}\text { Cadmium, copper, } \\
\text { chrome, nickel, zinc }\end{array}$ & Biocatalytic & Ureasa & Optical & Verma et al., 2010 \\
\hline Lead & & $\begin{array}{l}\text { bovine serum } \\
\text { albumin }\end{array}$ & $\begin{array}{l}\text { piezoelectric } \\
\text { quartz crystal } \\
\text { impedance }\end{array}$ & Yin et al., 2007 \\
\hline Lead & \begin{tabular}{|l|} 
Direct \\
structure- \\
competitive \\
detection \\
mode \\
\end{tabular} & \begin{tabular}{|l|}
$\begin{array}{l}\text { Monoclonal } \\
\text { antibody }\end{array}$ \\
\end{tabular} & $\begin{array}{l}\text { Gold nanoparticle- } \\
\text { modified optical } \\
\text { fiber }\end{array}$ & Lin \& Chung, 2008 \\
\hline Mercury & & $\begin{array}{l}\text { Envanescent wave } \\
\text { DNA-based } \\
\text { biosensor }\end{array}$ & Fiber optic sensor & Long et al., 2011 \\
\hline Copper and mercury & Biocatalytic & Glucose oxidase & Amperometric & $\begin{array}{l}\text { Ghica \& Brett, 2008; } \\
\text { Jian-Xiao et al., 2009 }\end{array}$ \\
\hline
\end{tabular}

Table 1. Most important biosensors used in the detection of pesticides, fertilizers and other pollutants.

\subsection{Biosensors as indicators of product acceptability}

Food quality involves nutritional and organoleptic characteristics important for consumers such as freshness, appearance, taste and texture. The food sensory basis is essential for the industry (Perez et al., 2007; Vadivambal \& Jayas, 2007).

A method to determine food freshness is by assessing food composition of products such as meats, fish, fruits and vegetables. During storage, compounds that provide aroma and 
abnormal flavors or may be harmful to consumer may be synthesized, indicating in most cases microbial growth and insufficient food safety (Serna et al., 2009).

Food freshness is negatively affected by storage time, incorrect packaging design, inadequate temperature and oxygen management during the handling of fruits and vegetables in modified atmosphere storage conditions.

Ethanol and methanol have been used as indicators of food freshness and quality of alcoholic beverages. Their determination is done by colorimetric, refractometric, chromatographic and spectrophotometric methods. Some of these techniques require expensive equipments and all require considerable time. These drawbacks can be overcome with the use of biosensors.

Biosensors that use whole cells or enzymes have been used for the detection of alcohol (Valach at al., 2009). Alcohol enzymatic biosensors described in the literature are mainly based on alcohol dehydrogenase and alcohol oxidase, and less commonly on catalase. Ethanol biosensors using alcohol oxidase as biorecognition element are the most abundant. Alcohol oxidase is an oligomeric enzyme responsible for the oxidation of low molecular weight primary alcohols, using molecular oxygen as the electron acceptor and producing acetaldehyde and hydrogen peroxide. Due to the strong oxidizing character of oxygen, the oxidation of alcohols by alcohol oxidase is irreversible. The reaction may be followed by measuring either $\mathrm{O}_{2}$ decline or $\mathrm{H}_{2} \mathrm{O}_{2}$ increase using optical or electrochemical detections.

Smyth et al. (1999) used a biosensor with immobilized enzymes alcohol oxidase and alcohol peroxidase and a chromogen, to detect injuries caused by low $\mathrm{O}_{2}$ in lettuce, cauliflower, broccoli and cabbage lightly processed and packed in a modified atmosphere. By measuring the ethanol accumulation in the free space, results obtained with this biosensor are similar to those obtained using gas chromatography. This biosensor could also be used to monitor ethanol during the storage of apples in a controlled atmosphere, the decay in potato tubers (Castillo et al., 2003), or in any other application where ethanol accumulation can be associated with quality loss. Similar research has been done to detect organic acids and sugars as indicators of fruit and vegetables maturity (Cañas \& Macias, 2004).

Hnaien et al. (2010) pioneered the construction of a conductimetric biosensor for the detection of ethanol in foods. The biosensor uses the enzymes ethanol oxidase and catalase co-immobilized on the surface of interdigitated thin-film electrodes. The transduction mode has the following advantages: (a) thin-film electrodes are suitable for miniaturization and large scale production using inexpensive technology, (b) it does not require any reference electrode and the differential mode measurements allow cancellation of many interferences, (c) it is not sensitive to light, (d) the driving voltage can be sufficiently low to significantly reduce power consumption, and (e) large spectrum of compounds of different nature can be determined on the basis of various reactions and mechanisms (Jaffrezic \& Dzyadevych, 2008).

Similarly, Asav \& Akyilmaz (2010) developed an amperometric biosensor for the determination of glucose and ethanol. The biosensor is based on the co-immobilization of alcohol oxidase and glucose oxidase on the same electrode by formation of self-assembled monolayers on a gold disc electrode. Measurements are based on monitoring decrease in current on reduction potential of tetrathiafulvalene (at $0.1 \mathrm{~V}$ vs. $\mathrm{Ag} / \mathrm{AgCl}$ ) by using a cyclic voltammetry method. Cyclic voltammograms were taken at a potential range between -0.1 and $0.4 \mathrm{~V}$ vs. $\mathrm{Ag} / \mathrm{AgCl}$ and correlations between decreases in biosensor responses and glucose oxidase or alcohol oxidase activity were monitored. 
Multiple compounds giving unpleasant flavors and aromas in foods can be potentially detected by biosensors. This is the case of the 2,4,6-trichloroanisole, a compound (Varelas et al., 2011) related to corks in wine bottles causing considerable losses to the wine industry. Varelas et al. (2011) developed a rapid novel biosensor system based on a bioelectric recognition assay. The sensor measured the electric response of cultured membraneengineered fibroblast cells suspended in an alginate gel matrix due to the change of their membrane potential in the presence of the analyte.

Fish freshness has been identified by the quantification of total percent inosine and hypoxanthine generated during fish postmortem changes (Hamada-Sato et al, 2005). Other process indicator compounds can be detected through biosensors, such as lactulose, a disaccharide formed during the thermal processing of milk that allows differentiating between UHT vs. sterilized in container milks.

The amount of starch, glucose, lactose, lecithin, and ethanol present in food, are indicators of quality and consumer acceptability. These compounds also serve as indicators of processing steps completion in manufactured food products. Biosensors technology for substance detection significantly reduces analysis time, and improves specificity, reliability and test sensitivity. These properties allow for real time decision making during food processing. A listing of biosensors used to evaluate food composition is presented by Serna et al. (2009).

Product quality standards are also determined by sensory analysis. During sensory evaluation, a set of techniques to measure properties such appearance, smell, taste and texture when chewing or eating food are used to determine human sensations. However, standardization and accreditation methods for sensory quality analysis are still needed for the certification of food products.

Using expert panels, Pérez et al. (2007) proposed a set of accredited methods for the sensory evaluation of the "Idiazabal" cheese that could be generalized to any type of food and drink as a reference for sensory accreditation. The use of biosensors instead of expert panels in sensory analysis seems to be a good alternative. Electronic and bioelectronic tongues, which could be known as taste sensors, are the advanced and emerging analytical technologies simulating the taste detection modality of the human tongue by means of electrochemical sensors or biosensor arrays.

Pioggia et al. (2007) characterized five compounds with different chemical characteristics and determined taste perceptions, using an electrical impedance biosensor. Five sensors of three different types based on carbon nanotubes or carbon black dispersed in polymeric matrices and doped polythiophenes composed the array. Fifty different solutions eliciting the five basic tastes (sodium chloride, citric acid, glucose, glutamic acid and sodium dehydrocholate for salty, sour, sweet, umami and bitter, respectively) at 10 concentration levels comprising the human perceptive range were analyzed. The impedentiometric composite sensor array was shown to be sensitive, selective and stable for using it in an electronic tongue.

Taste substances are getting through the biological membrane of gustatory cells in the taste buds of tongue. Taste is perceived when the information on taste substances is transduced into an electrical signal, which is transmitted along the nerve fiber to the brain. Electronic and probably bioelectronic tongues are known as two promising tools for the taste assessment of the foodstuffs. In a review article, Ghasemi-Varnamkhasti et al. (2011) concluded that bioelectronic tongues would be a useful tool for process control and although, application of electronic tongue has been reported for alcoholic beers, up to now, 
no research has been published on the flavor evaluation of non alcoholic beer by means of bioelectronics tongue.

\section{Potential use of biosensors in hazard analysis and critical control points (HACCP)}

A quality management system should include quality control, quality assurance and a continuous improvement system. In quality management of agri-food processes, hazard analysis and critical control points (HACCP) is considered as the most effective system to ensure food safety. HACCP can also be used as a food quality control system (Ropkins \& Beck, 2000).

Well implemented HACCP systems can be used to improve processing efficiency and the quality of food products in order to meet the client needs, and even as defense arguments in litigations. Although HACCP systems are great tools, microbiological contamination of products from biological origin will continue to be the greatest threat in food production. As mentioned before, bacteria counts can be detected by microbial cultures, which are very effective, but require expensive and time consuming techniques to yield reliable results. Many other methods have been proposed for the rapid detection, isolation, identification and enumeration of bacteria, including among others, impedimetric detection, automated cells counting, and immunoassays.

Biosensors have been adapted to detect or quantify analytes in systems in-line (Rasooly, 2001). The HACCP system can be used to verify that a given process is under control, since high biosensor sensitivity allows the detection of pathogenic microorganisms, pesticides, herbicides and other contaminants in hours or minutes (Luo et al., 2009; Mostafa, 2010).

In a HACCP system setup, the ATP bioluminescence method is very suitable for monitoring bacteria in-line, since it does not need prior bacteria growth. The ATP bioluminescence assay is based on the detection of ATP present in living organisms through the luciferinluciferase enzymatic system.

Luo et al. (2009) developed a low-cost biosensor to detect bacterial counts, with easy operation and rapid response, based on adenosine 50-triphosphate (ATP). The biosensor is composed of a key sensitive element and a photomultiplier tube as a detector element. The disposable sensitive element consists of a sampler, a cartridge where intracellular ATP is chemically extracted from bacteria, and a microtube where the extracted ATP reacts with the luciferin-luciferase reagent to produce bioluminescence. The bioluminescence signal is transformed into relevant electrical signal by the detector and further measured with a homemade luminometer.

In HACCP systems implemented for fisheries, histamine can be used as a quality indicator for the evaluation of fresh fish. Hamada-Sato et al. (2005) considered that raw fish freshness could be estimated by the " $\mathrm{K}$ " freshness value. The $\mathrm{K}$ value is the total percent of inosine and hypoxanthine to that of ATP-related compounds, and it has shown a good relationship with fish muscle changes. Postmortem adenine phosphate nucleotides (ATP, ADP, and AMP) contents decline rapidly and inosine monophosphate (IMP) contents increase sharply at $0^{\circ} \mathrm{C}$ within about $24 \mathrm{~h}$ after death. Furthermore, inosine and hypoxanthine contents increase when IMP contents decline. Hamada-Sato et al. (2005) simplified the K value to KI since it represents "the ratio (\%) of total amount of inosine and hypoxanthine to that of IMP, inosine and hypoxantine". 
A biosensor to determine the KI value has already been developed and it is commercially available (Tokaseiki Ltd.). The biosensor consists of two enzyme reactors, two oxygen electrodes, a peristaltic pump, an A/D converter, a microcomputer and a data logger. Inosine in fish muscle is converted into hypoxanthine by nucleoside phosphorylase in enzyme reactor A, followed by the oxidation of hypoxanthine by xanthine oxidase (XOD) in the same reactor. The total amount of inosine and hypoxanthine was determined from the output of the electrode corresponding to the amount of oxygen consumed by hypoxanthine oxidation. IMP is converted into inosine by nucleotidase (NT) in enzyme reactor $B$, followed by the same reaction in enzyme reactor $\mathrm{A}$.

The total amount of IMP, inosine and hypoxanthine was determined from the output of the electrode corresponding to the amount of oxygen consumed by hypoxanthine oxidation. Fifty microliters of the sample solution were injected through the injection port, and after about $3 \mathrm{~min}$, the obtained results were displayed on the screen (Okuma et al., 1992).

Similarly, the concentration of amino acids (e.g., lysine) obtained by fermentation and used as supplements in animal feed have been controlled with the enzyme lysine oxidase. Amperometric biosensors have been used to measure lactic acid used to control the acidity and crust formation in cheese, assessed using the enzyme lactate oxidase. These biosensors can be integrated into a HACCP system to monitor process acceptability.

\section{Conclusions}

The use of biosensors technology for food safety will facilitate complying with international quality and safety standards, allowing for the efficient, safe and reliable detection and quantification of pathogenic microorganisms involved in food borne illnesses and inorganic contaminants that threaten consumer health. However, the detection of small concentrations of chemical and biological polluting substances in products for human and animal consumption is still needed.

The selectivity, specificity, and rapid response depend on the biosensor's reception and transduction systems, since they are based on recording reactions that generate physical, chemical and/or immunological changes. This form of reading that allows for a rapid response is ideal in the agri-food process control.

Although biosensors technology is approximately 50 years old, there are several fields that are still under study. A continue search for new recognition elements which comply with minimum wear characteristics and are absent of inhibitory substances that block analyte detection must be done. In the same way, receptors with greater stability for the analyte are also needed.

The detection of pathogenic microorganisms with the use of biosensors shows advantages when compared to traditional methods. In addition to easy handling, biosensors provide timely detection and on line process control. The complex metabolism of pathogenic bacteria and the defense reactions produced by the guest organisms are also used to build biosensors. Furthermore, antigen-antibody interactions are efficient and selective, and the detection speed will depend on the sensitivity of the transduction system and on the method used for signal amplification.

Pesticides, fertilizers, and heavy metals can be quickly detected in small quantities with biosensors, facilitating in situ implementation in pre- and post-harvest processes. Transduction, electrochemical and optical methods provide better detection sensitivity in these cases. 
In the agri-food industry, biosensors have been useful to assess the freshness of raw materials such as meat, fish, fruits and vegetables. In these cases, biosensors detect compounds that provide abnormal flavors and aromas, indicating microbial growth and food safety problems. However, although biosensors developed in recent years are efficient and some of them successfully used in the industry, their use is limited by the need for receiver renovation and calibration and the adequate control of system variables.

\section{References}

Akar, S., Tek, V., Bange, A., Lagos, L., Gill, P., Munroe, N. \& Thundat, T. (2010). Development of a biosensor for detection of phosphate species in uranium contaminated ground water and wastewater sediments. WM2010 Conference, Phoenix, AZ, USA, March $7-11,2010$

Almeida, M., Silveira, C. \& Moura, J. (2007). Biosensing nitrite using the system nitrite redutase/Nafion/methyl viologen-A voltammetric study. Biosensors and Bioelectronics, Vol. 22, No. 11, pp. 2485-2492

Arbault, P., Buecher, V., Poumerol, S. \& Sorin, M. (2000). Study of an ELISA method for the detection of E. coli O157 in food. Progress in Biotechnology, Vol. 17, pp. 359-368.

Asav, E. \& Akyilmaz, E. (2010). Preparation and optimization of a bienzymic biosensor based on self-assembled monolayer modified gold electrode for alcohol and glucose detection. Biosensors and Bioelectronics, Vol. 25, No. 5, pp. 1014-1018

Bagal-Kestwal, D., Karve, M., Kakadeb, B. \& Pillai, V. (2008). Invertase inhibition based electrochemical sensor for the detection of heavy metal ions in aqueous system: Application of ultra-microelectrode to enhance sucrose biosensor's sensitivity. Biosensors and Bioelectronics, Vol. 24, No. 4, pp. 657-664.

Cabrera, L., Witte, J., Victor. B., Vermeiren, L., Zimic, M., Brandt, J. \& Geysen, D. (2009). Specific detection and identification of African trypanosomes in bovine peripheral blood by means of a PCR-ELISA assay. Veterinary Parasitology, Vol. 164, No. 2-4, pp. 111-117.

Cañas, A. \& Macias, M. (2004). Desarrollo de un sistema sensor para la cuantificación de glucosa en jugos de frutas. Revista de la Sociedad Química de Mexico, Mexico, Vol. 48, No. 8, pp. 106-110

Castillo, J., Gáspár, S., Sakharov, I. \& Csöregi, E. (2003). Bienzyme biosensors for glucose, ethanol and putrescine built on oxidase and sweet potato peroxidase. Biosensors and Bioelectronics, Vol. 18, No. 5-6, pp. 705-714.

Chen, S., Huang, J., Du, D., Li, J., Tu, H., Liu, D. \& Zhang, A. (2010). Methyl parathion hydrolase based nanocomposite biosensors for highly sensitive and selective determination of methyl parathion. Biosensors and Bioelectronics, Article in Press, doi:10.1016/j.bios.2011.04.025.

Chouteau, C., Dzyadevych, S., Durrieu, C. \& Chovelon, J. (2005). A bi-enzymatic whole cell conductometric biosensor for heavy metal ions and pesticides detection in water samples. Biosensors and Bioelectronics, Vol. 21, No. 2, pp. 273-281

Darnton, N., Turner, L., Rojevsky, S. \& Berg, H. (2007). On Torque and Tumbling in Swimming Escherichia coli. Journal of Bacteriology, Vol. 189, No. 5, pp. 1756-1764. ISBN 0021-9193

Deng, L., Xu, Y. \& Huang, J. (2008). Developing a double-antigen sandwich ELISA for effective detection of human hepatitis B core antibody. Comparative Immunology, Microbiology \& Infectious Diseases, Vol. 31, No. 6, pp. 515-526

Deo, R., Wang, J., Block, I., Mulchandani, A., Joshi, K., Trojanowicz, M., Scholz, F., Chen, W. \& Lin, Y. (2005). Determination of organophosphate pesticides at a carbon 
nanotube/organophosphorus hydrolase electrochemical biosensor. Analytica. Chimica Acta, Vol. 530, No. 2, pp. 185-189.

Du, D., Huang, X., Cai, J. \& Zhang, A. (2007). Amperometric detection of triazophos pesticide using acetylcholinesterase biosensor based on multiwall carbon nanotube-chitosan matrix. Sensors and Actuators B: Chemical, Vol. 127, No.2, pp. 531-535

Du, D., Wang, M., Cai, J. \& Zhang, A. (2010). Sensitive acetylcholinesterase biosensor based on assembly of $\beta$-cyclodextrins onto multiwall carbon nanotubes for detection of organophosphates pesticide. Sensors and Actuators B: Chemical, Vol. 146, No. 1, pp. 337-341

Dutta, K., Bhattacharyay, D., Mukherjee, A., Setford, S., Turner, A. \& Sarkar, P. (2008). Detection of pesticide by polymeric enzyme electrodes. Ecotoxicology and Environmental Safety, Vol. 69, No. 3, pp. 556-561

Dzyadevych, S., Soldatkin, A., Arkhypova, V., El'skaya, A. \& Chovelon, J. (2005). Earlywarning electrochemical biosensor system for environmental monitoring based on enzyme inhibition. Sensors and Actuators B: Chemical, Vol. 105, No. 1, pp. 81-87

FAO (1996). Plan de Acción de la Cumbre Mundial sobre la Alimentación, párrafo 1. In: Declaración de Roma sobre la Seguridad Alimentaria Mundial y Plan de Acción de la Cumbre Mundial sobre la Alimentación. Cumbre Mundial sobre la Alimentación, 13-17 de noviembre de 1996, FAO, 43 p., Roma, Italia,

FAO/WHO (2004). Risk assessment of Listeria monocytogenes in ready to eat foods. Microbiological Risk Assessment Series, No. 4, Interpretive Summary. ISBN 9241562617 (WHO), Available from

http://www.who.int/foodsafety/publications/micro/mra_listeria/en/index.html

Fohlerová, Z., Skládal, P. \& Turánek, J. (2007). Adhesion of eukaryotic cell lines on the gold surface modified with extracellular matrix proteins monitored by the piezoelectric sensor. Biosensors and Bioelectronics, Vol. 22, No. 9-10, pp. 1896-1901

Geng, T., Morgan, M. \& Bhunia A. (2004). Detection of Low Levels of Listeria monocytogenes Cells by Using a Fiber-Optic Immunosensor. Applied and Environmental Microbiology, Vol. 70, No. 10, pp. 6138-6146, ISBN 0099-2240

Gfeller, K., Nugaeva, N. \& Hegner, M. (2005). Micromechanical oscillators as rapid biosensor for the detection of active growth of Escherichia coli. Biosensors and Bioelectronics, Vol. 21, No. 3, pp. 528-533

Ghasemi-Varnamkhasti, M., Mohtasebi, S., Rodriguez-Mendez, M., Siadat, M., Ahmadi, H. \& Razavi, S. (2011). Electronic and bioelectronic tongues, two promising analytical tools for the quality evaluation of non alcoholic beer. Trends in Food Science $\mathcal{E}$ Technology, Vol. 22, No. 5, pp. 245-248

Ghica, M. \& Brett, C. (2008). Glucose oxidase inhibition in poly(neutral red) mediated enzyme biosensors for heavy metal determination. Microchimica Acta, Vol. 163, No. 3-4, 185-193.

Gong, J., Wang, L. \& Zhang, L. (2009). Electrochemical biosensing of methyl parathion pesticide based on acetylcholinesterase immobilized onto Au-polypyrrole interlaced network-like nanocomposite. Biosensors and Bioelectronics, Vol. 24, No. 7, pp. 2285-2288

Guntupalli, R., Hu, J., Lakshmanan, R., Huang, T., Barbaree, J. \& Chin, B. (2007). A magnetoelastic resonance biosensor immobilized with polyclonal antibody for the detection of Salmonella typhimurium. Biosensors and Bioelectronics, Vol. 22, No. 7, pp. 1474-1479

Haasnoot, W., Du Pre, J., Cazemier, G., Kemmers-Voncken, A., Verheijen, R. \& Jansen, B. (2000). Monoclonal antibodies against a sulfathiazole derivative for the 
immunochemical detection of sulphonamides. Food and Agricultural lmmunology, Vol. 12, No. 2, pp. 127-138

Hamada-Sato, N., Usui, K., Kobayashi, T., Imada, C. \& Watanabe, E. (2005). Quality assurance of raw fish based on HACCP concept. Food Control, Vol. 16, No. 4, pp. 301-307

Hiemstra, M. \& De Kok, A. (1994). Determination of N-methylcarbamate pesticides in environmental water samples using automated on-line trace enrichment with exchangeable cartridges and high-performance liquid chromatography. Journal of Chromatography, Vol. 667, No., pp. 155-166

Hildebrandt, A., Bragos, R., Lacorte, S. \& Marty, J. (2008). Performance of a portable biosensor for the analysis of organophosphorus and carbamate insecticides in water and food. Sensors and Actuators B: Chemical, Vol. 133, No. 1, pp. 195-201

Hnaien, M., Lagarde, F. \& Jaffrezic-Renault, N. (2010). A rapid and sensitive alcohol oxidase/catalase conductometric biosensor for alcohol determination. Talanta, Vol. 81 , No. 1-2, 222-227

Jaffrezic-Renault, N. \& Dzyadevych, S. (2008). Conductometric Microbiosensors for Environmental Monitoring. Sensors, Vol. 8, No. 4, pp. 2569-2588

Jian-xiao, L., Xiang-min, X., Lin, T. \& Guang-ming, Z. (2009). Determination of trace mercury in compost extract by inhibithion based glucose oxidase biosensor. Transactions of Nonferrous Metals Society of China.Vol. 19, No. 1, pp.235-240

Kim, N., Park, I. \& Kim, D. (2007). High-sensitivity detection for model organophosphorus and carbamatepesticide with quartz crystal microbalance-precipitation sensor. Biosensors and Bioelectronics, Vol. 22, No. 8, pp. 1593-1599

Kumar, J., Kumar, S. \& D'Souza, J. (2006). Optical microbial biosensor for detection of methyl parathion pesticide using Flavobacterium sp. whole cells adsorbed on glass fiber filters as disposable biocomponent. Biosensors and Bioelectronics, Vol. 21, No. 11, pp. $2100-2105$

Kumar, J. \& D'Souza, S. (2010). An optical microbial biosensor for detection of methyl parathion using Sphingomonas sp. immobilized on microplate as a reusable biocomponent. Biosensors and Bioelectronics, Vol. 26, No. 4, pp. 1292-1296

Kuralay, F., Ozyoruk, H. \& Yıldız, A. (2006). Amperometric enzyme electrode for urea determination usingimmobilized urease in poly(vinylferrocenium) film. Sensors and Actuators B: Chemical, Vol. 114, No. 1, pp. 500-506

Leonard, P., Hearty, S., Quinn, J. \& O'Kennedy, R. (2004). A generic approach for the detection of whole Listeria monocytogenes cells in contaminated samples using surface plasmon resonance. Biosensors and Bioelectronics, Vol. 19, No. 10, 1331-1335

Lin, H., Lu, Q., Ge, S., Cai, Q. \& Grimes, C. (2010). Detection of pathogen Escherichia coli O157:H7 with a wireless magnetoelastic-sensing device amplified by using chitosan-modified magnetic $\mathrm{Fe}_{3} \mathrm{O}_{4}$ nanoparticles. Sensors and Actuators B: Chemical, Vol 147, No. 1, pp. 343-349

Lin, T. \& Chung, M. (2008). Using monoclonal antibody to determine lead ions with a localized surface plasmon resonance fiber-optic biosensor. Sensors, Vol. 8, No. 1, pp. 582-593.

Long, F., Gao, C., Shi, H., He, M., Zhu, A., Klibanov, A. \& Gu, A. (2011). Reusable evanescent wave DNA biosensor for rapid, highly sensitive, and selective detection of mercury ions, Biosensors and Bioelectronics, Article in Press, doi: 10.1016/j.bios.2011.03.022

Lu, Y., Yang, W., Shi, L., Li, L., Alam, M., Guo, S. \& Miyoshi, S. (2009). Specific Detection of Viable Salmonella Cells by an Ethidium Monoazide-Loop Mediated Isothermal 
Amplification (EMA-LAMP) Method. Journal of Health Science, Vol. 55, No. 5, pp. 820-824

Luo, J., Liu, X., Tian, Q., Yue, W., Zeng, J., Chen, G. \& Cai, X. (2009). Disposable bioluminescence-based biosensor for detection of bacterial count in food. Analytical Biochemistry, Vol. 394, No. 1, pp. 1-6

Meng, J. \& Doyle, M. (2002). Introduction. Microbiological food safety. Microbes and Infection, Vol. 4, No. 4, pp. 395-397

Mostafa, G. A. (2010). Electrochemical Biosensors for the detection of pesticides. The Open Electrochemistry Journal. Vol. 2, pp. 22-42.

Nowak B., Müffling T., Chaunchom S. \& Hartung, J. (2007). Salmonella contamination in pigs at slaughter and on the farm: A field studyusing an antibody ELISA test and a PCR technique. International Journal of Food Microbiology, Vol. 115, No. 3, pp. 259-267

Ocampo A., March, C. \& Montoya, A. (2007). Inmunosensores piezoeléctricos: revisión general y su aplicación en el análisis de pesticidas. Revista EIA, Escuela de Ingeniería de Antioquia, Medellín, Colombia, No. 7, pp. 97-110, ISSN 1794-1237

Okuma, H., Takahashi, H., Yazawa, S., Sekimukai, S. \& Watanabe, E., 1992. Development of a system with double enzyme reactors for the determination of fish freshness. Analytica Chimica Acta, Vol. 260, No. 1, pp. 93-98

On, S. (2001). Taxonomy of Campylobacter, Arcobacter, Helicobacter and related bacteria: current status, future prospects and immediate concerns. Journal of Applied Microbiology, Vol. 90, No. S6, pp. 1S-15S.

Park, J., Kurosawa, S., Aizawa, H., Hamano, H., Harada, Y., Asano, S., Mizushima, Y. \& Higaki, M. (2006). Dioxin immunosensor using anti-2,3,7,8-TCDD antibody which was produced with mono 6-(2,3,6,7-tetrachloroxanthene-9-ylidene) hexyl succinate as a hapten. Biosensors and Bioelectronics, Vol. 22, No. 3, pp. 409-414

Patel, P. (2002). (Bio)sensors for measurement of analytes implicated in food safety: a review. Trends in Analytical Chemistry, Vol. 21, No. 2, pp. 96-115

Pathirana, S., Barbaree, J., Chin, B., Hartell, M., Neely, W. \& Vodyanoy, V. (2000). Rapid and sensitive biosensor for Salmonella. Biosensors and Bioelectronics, Vol. 15, No. 3-4, pp. 135-141

Pavlov, V., Xiao, Y. \& Willner, I. (2005). Inhibition of the acetylcholine esterase-stimulated growth of au nanoparticles: nanotechnology-based sensing of nerve gases. Nano Letters. Vol. 5, No.4, pp. 649-653

Pellicer, K., Hoyo, G., Brocardo, M., Aliverti, V., Aliverti, F. \& Copes, J. (2009). Effect of Chlorhidric and Lactic Acid on the Development of Thirty Strains of Listeria spp. from Foods Stuffs. Revista de la Facultad de Ciencias Veterinarias, Universidad Central de Venezuela, Vol. 50, No. 1, pp. 19-22, ISBN 0048-7724

Pérez Elortondo, F., Ojeda, M., Albisu, M., Salmerón, J., Etayo, I. \& Molina, M. (2007). Food quality certification: An approach for the development of accredited sensory evaluation methods. Food Quality and Preference, Vol. 18, No. 2, pp. 425-439

Pioggia, G., Di Francesco, F., Marchetti, A., Ferro, M. \& Ahluwalia, A. (2007). A composite sensor array impedentiometric electronic tongue Part I. Characterization. Biosensors and Bioelectronics, Vol. 22, No. 11, pp. 2618-2623

Pribyl, J., Hepel, M. \& Skládal, P. (2006). Piezoelectric immunosensors for polychlorinated biphenyls operatingin aqueous and organic phases. Sensors and Actuators B: Chemical, Vol. 113, No. 2, pp. 900-910.

Pribyl, J., Hepel, M., Halámek, J. \& Skládal, P. (2003). Development of piezoelectric immunosensors for competitive and direct determination of atrazine. Sensors and Actuators B: Chemical, Vol. 91, No. 1-3, pp. 333-341 
Rahman, M., Park, D., Chang, S., McNeil, C. \& Shim, Y. (2006). The biosensor based on the pyruvate oxidase modified conducting polymer for phosphate ions determinations. Biosensors and Bioelectronics, Vol. 21, No. 7, pp. 1116-1124

Rasooly, A. (2001). Surface plasmon resonance analysis of Staphylococcal enterotoxin B in food. Journal of Food Protection, Vol. 64, No. 1, pp. 37-43

Ropkins, K. \& Beck, A. (2000). Evaluation of worldwide approaches to the use of HACCP to control food safety. Trends in Food Science and Technology, Vol. 11, No. 1, pp. 10-21

Ryan, K \& Ray, C. (Eds). (2010) Sherris medical microbiology, Fifth edition. McGraw Hill Companies, Inc. 1026 p. ISBN 978-0-07-160402-4, USA

Sánchez, J., Jiménez, S., Navarro, R. \& Villarejo, M. (2009). Patógenos Emergentes en la Línea de Sacrificio de Porcino. Fundamentos de Seguridad Alimentaria. Ediciones Díaz de Santos, 209 p. ISBN 978847978922 0, España

Schöning, M., Arzdorf, M., Mulchandani, P., Chen, W. \& Mulchandani, A. (2003). Towards a capacitive enzyme sensor for direct determination of organophosphorus pesticides: fundamental studies and aspects of development. Sensors, Vol. 3, No. 6, 119-127

Serna, L., Zetty A. \& Ayala, A. (2009). Use of enzymatic biosensors as quality indices: a synopsis of present and future trends in the food industry. Chilean Journal of Agricultural Research, Vol. 69, No. 2, pp. 270-280

Seo, K., Brackett, R. \& Frank, J. (1998). Rapid detection of Escherichia coli O157:H7 using immunomagnetic flow cytometry in ground beef, apple juice, and milk. International Journal of Food Microbiology, Vol. 44, No. 1-2, pp. 115-123.

Shimomura, T., Itoh, T., Sumiya, T., Mizukami, F. \& Ono, M. (2009). Amperometric biosensor based on enzymes immobilized in hybrid mesoporous membranes for the determination of acetylcholine. Enzyme and Microbial Technology, Vol. 45, No. 6$7,443-448$

Silveira, C., Gomes, S., Araújo, A., Montenegro, B., Todorovic, S., Viana, A., Silva, R., Moura, J. \& Almeida, M. (2010). An efficient non-mediated amperometric biosensor for nitrite determination. Biosensors and Bioelectronics, Vol. 25, No. 9, pp. 2026-2032

Sismani, C., Kousoulidou, L. \& Patsalis, P. (2008). Molecular biomethods handbook. 2nd Edition.Humana Prees, 1124 p., ISBN 1603273700, Totowa, NJ

Smyth, A., Talasila, P. \& Cameron, A. (1999). An ethanol biosensor can detect low-oxygen injury in modified atmosphere packages of fresh-cut produce. Postharvest Biology and Technology, Vol. 5, No. 2, pp. 127-134

Sohail, M. \& Adeloju, S. (2008). Electroimmobilization of nitrate reductase and nicotinamide adenine dinucleotide into polypyrrole films for potentiometric detection of nitrate. Sensors and Actuators B: Chemical, Vol. 133, No. 1, pp. 333-339

Székács, A., Trummer, N., Adányi, N., Váradi, M. \& Szendrö, I. (2003). Development of a non-labeled immunosensor for the herbicide trifluralin via OWLS detection. Analytica Chimica Acta, Vol. 487, No. 1, pp. 31-42

Tang, H., Zhang, W., Geng, P., Wang, Q., Jin, L., Wu, Z. \& Lou, M. (2006). A new amperometric method for rapid detection of Escherichia coli density using a selfassembled monolayer-based bienzyme biosensor. Analytica Chimica Acta, Vol. 562, No. 2, pp. 190-196

Tims, T. \& Lim, D. (2003). Confirmation of viable E. coli O157:H7 by enrichment and PCR after rapid biosensor detection. Journal of Microbiological Methods, Vol. 55, No. 1, pp. 141- 147

Trivedi, U., Lakshminarayana, D., Kothari, I., Patel, N., Kapse, H., Makhija, K., Patel, P. \& Panchal, C. (2009). Potentiometric biosensor for urea determination in milk. Sensors and Actuators B: Chemical, Vol. 140, No. 1, pp. 260-266 
Tsai, H., Doong, R., Chiang, H. \& Chen, K. (2003). Sol-gel derived urease- based optical biosensor for the rapid determination of heavy metals. Analytica Chimica Acta, Vol.481, No. 1, pp. 75-84.

Turner, N., Subrahmanyam, S. \& Piletsky, S. (2009). Analytical methods for determination of mycotoxins: A review. Analytica Chimica Acta, Vol. 632, No. 2, pp. 168-180

Vadivambal, R. \& Jayas, D. (2007). Changes in quality of microwave-treated agricultural products: a review. Biosystems Engineering, Vol. 98, No. 1, pp. 1-16

Valach, M., Katrlik, J., Sturdik, E. \& Gemeiner, P. (2009). Ethanol Gluconobacter biosensor designed for flow injection analysis: Application in ethanol fermentation off-line monitoring. Sensors and Actuators B: Chemical, Vol. 138, No. 2, pp. 581-586

Van der Merwe, P. (May 2011) Surface Plasmon Resonance. Available from http://users.path.ox.ac.uk/ vdmerwe/Internal/spr.PDF.

Varelas, V., Sanvicens, N., Pilar-Marco, M. \& Kintzios, S. (2011). Development of a cellular biosensor for the detection of 2,4,6-trichloroanisole (TCA). Talanta, Vol. 84, No. 3, pp. $936-940$

Vasquez de Plata, G. (2003). La Contaminación de los Alimentos, un Problema por Resolver. Salud UIS, Vol. 35, pp. 48-57

Verma, N., Kumar, S. \& Kaur, H. (2010). Fiber Optic Biosensor for the Detection of Cd in Milk. Journal of Biosensors and Bioelectronics, 1:102. doi:10.4172/2155-6210.1000102.

Waswa, J., Irudayaraj, J. \& DebRoy, C. (2007). Direct detection of E. Coli O157:H7 in selected food systems by a surface plasmon resonance biosensor. Food Science and Technology, Vol. 40, No. 2, pp. 187-192

Wei, D., Oyarzabal, O., Huang T., Balasubramanian, S., Sista, S. \& Simonian, A. (2007). Development of a surface plasmon resonance biosensor for the identification of Campylobacter jejuni. Journal of Microbiological Methods, Vol. 69, No. 1, pp. 78-85

White, D., Zhao, S., Simjee, S., Wagner, D. \& McDermott, P. (2002). Antimicrobial resistance of foodborne pathogens. Microbes and Infection, Vol. 4, No. 4, pp. 405-412

WHO (2000). Factsheet No 255: Campylobacter. World Health Organization, Available from http://www.who.int/mediacentre/factsheets/fs255/en

WHO (2005). Factsheet No 125: Enterohaemorrahic Escherichia coli (EHEC). World Health Organization, Available from http://www.who.int/mediacentre/factsheets/fs125/en/

Yin, J., Wei, W., Liu, X., Kong, B., Wu, L. \& Gong, S. (2007). Immobilization of bovine serum albumin as a sensitive biosensorfor the detection of trace lead ion in solution by piezoelectric quartz crystal impedance. Analytical Biochemistry, Vol. 360, No. 1, pp. 99-104

Yokoyama, K., Ikebukuro, H., Tamiya, E., Karube, I., Ichiki, N. \& Arikawa, Y. (1995). Highly sensitive quartz crystal immunosensors for multisample detection of herbicides. Analytica Chimica Acta, Vol. 304, No. 2, pp. 139-145

Zhang, Y., Muench, S., Schulze, H., Perz, R., Yang, B., Schmid, R. \& Bachmann, T. (2005). Disposable biosensor test for organophosphate and carbamate insecticides in milk. Journal of Agricultural and Food Chemistry, Vol. 53, No. 13, pp. 5110-5115

Zhang, Z., Jaffrezic-Renault, N., Bessueille, F., Leonard, D., Xia, S., Wang, X., Chen, L. \& Zhao, J. (2008). Development of a conductometric phosphate biosensor based on trilayer maltose phosphorylase composite films. Analytica Chimica Acta, Vol. 615, No. 1, pp. 73-79 


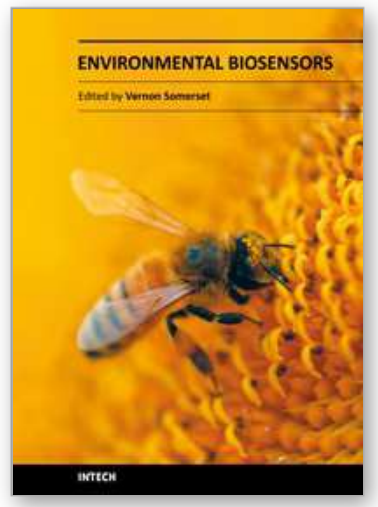

\author{
Environmental Biosensors \\ Edited by Prof. Vernon Somerset
}

ISBN 978-953-307-486-3

Hard cover, 356 pages

Publisher InTech

Published online 18, July, 2011

Published in print edition July, 2011

This book is a collection of contributions from leading specialists on the topic of biosensors for health, environment and biosecurity. It is divided into three sections with headings of current trends and developments; materials design and developments; and detection and monitoring. In the section on current trends and developments, topics such as biosensor applications for environmental and water monitoring, agroindustry applications, and trends in the detection of nerve agents and pesticides are discussed. The section on materials design and developments deals with topics on new materials for biosensor construction, polymerbased microsystems, silicon and silicon-related surfaces for biosensor applications, including hybrid film biosensor systems. Finally, in the detection and monitoring section, the specific topics covered deal with enzyme-based biosensors for phenol detection, ultra-sensitive fluorescence sensors, the determination of biochemical oxygen demand, and sensors for pharmaceutical and environmental analysis.

\title{
How to reference
}

In order to correctly reference this scholarly work, feel free to copy and paste the following:

Liliana Serna-Cock and Jeyson G. Perenguez-Verdugo (2011). Biosensors Applications in Agri-food Industry, Environmental Biosensors, Prof. Vernon Somerset (Ed.), ISBN: 978-953-307-486-3, InTech, Available from: http://www.intechopen.com/books/environmental-biosensors/biosensors-applications-in-agri-food-industry

\section{INTECH}

open science | open minds

\author{
InTech Europe \\ University Campus STeP Ri \\ Slavka Krautzeka 83/A \\ 51000 Rijeka, Croatia \\ Phone: +385 (51) 770447 \\ Fax: +385 (51) 686166 \\ www.intechopen.com
}

\author{
InTech China \\ Unit 405, Office Block, Hotel Equatorial Shanghai \\ No.65, Yan An Road (West), Shanghai, 200040, China \\ 中国上海市延安西路65号上海国际贵都大饭店办公楼 405 单元 \\ Phone: +86-21-62489820 \\ Fax: +86-21-62489821
}


(C) 2011 The Author(s). Licensee IntechOpen. This chapter is distributed under the terms of the Creative Commons Attribution-NonCommercialShareAlike-3.0 License, which permits use, distribution and reproduction for non-commercial purposes, provided the original is properly cited and derivative works building on this content are distributed under the same license. 